\title{
Rituximab retherapy in patients with relapsed aggressive $B$ cell and mantle cell lymphoma
}

\author{
Andrea Borgerding • Justin Hasenkamp • \\ Bertram Glaß • Gerald Wulf • Lorenz Trümper
}

Received: 7 July 2009 /Accepted: 13 August 2009/Published online: 2 September 2009

(C) The Author(s) 2009. This article is published with open access at Springerlink.com

\begin{abstract}
Neither effective salvage regimens nor the outcome and response to retherapy with rituximab containing chemotherapy have been defined for rituximab pretreated patients with relapsing aggressive lymphoma. We report here a single-centre retrospective outcome analysis of second-line immunochemotherapy with rituximab. In 28 patients with relapsed or refractory diffuse large B cell lymphomas, first-line immunochemotherapy had induced objective responses in 18 patients. Nine of 28 patients responded to rituximab containing salvage therapy, leading to a median overall survival of 243 days after start of second immunochemotherapy. Long-term disease free survivors (1,260 and 949 days) were restricted to the group of twelve patients that had received allogeneic stem cell transplantation as consolidation therapy. In 21 patients with relapsed mantle cell lymphomas (MCL), 19 patients had reached remissions with first-line therapy. Of those, 16 patients experienced responses to salvage therapy with a median overall survival of 226 days. Noteworthy, none of patients with initial non-responding disease reached a remission with second immunochemotherapy. Seven
\end{abstract}

\footnotetext{
A. Borgerding $\cdot$ J. Hasenkamp $\cdot$ G. Wulf $\cdot$ L. Trümper Department of Hematology and Oncology, Georg-August-University Goettingen, 37075 Goettingen, Germany

B. Glaß

Section for Stem Cell Transplantation, Asklepios Klinik Sankt Georg, 20099 Hamburg, Germany

A. Borgerding $(\bowtie)$

Department of Hematology and Oncology, Georg-August-University of Goettingen,

Robert-Koch-Str. 40,

37099 Goettingen, Germany

e-mail: a.borgerding@med.uni-goettingen.de
}

patients with MCL stayed free from progression after high-dose therapy with autologous or allogeneic stem cell transplantation in two and five cases, respectively. In summary, responses to repeated immunotherapy with rituximab were observed in approximately one third and two thirds of initially responding patients with aggressive B cell lymphoma and mantle cell lymphoma, respectively, but not in primarily refractory disease. Lasting remissions were achieved only by high-dose chemotherapy with stem cell transplantation.

Keywords Lymphoma $\cdot$ Relapse $\cdot$ Rituximab

\section{Introduction}

The addition of the monoclonal anti-CD20 antibody rituximab to standard chemotherapy regimens significantly improved treatment results for patients with aggressive B cell non-Hodgkin lymphoma, increasing response rates, as well as progression free and overall survival of patients in all prognostic subgroups [1-4]. Approximately one third of patients with diffuse large B cell lymphoma (DLBCL), however, experience relapse of disease [3-5], and treatment of such patients remains a major problem. For patients who had not received initial immunochemotherapy (ICT) with rituximab-containing regimens, several studies showed that the addition of rituximab increased the response rates to salvage protocols such as dexamethasone, high-dose cytarabine, and cisplatin (DHAP) [6], ifosfamide, carboplatin, and etoposide (ICE) [7], or gemcitabine/oxaliplatin [8], allowing to proceed to high-dose consolidation followed by stem cell transplantation. The PARMA trial established high-dose chemotherapy with autologous stem cell transplantation as the standard approach for patients with 
chemo-sensitive relapsed lymphoma disease [9]. Recently Martin et al. reported a series of 163 patients with aggressive B cell lymphoma confirming the role of intensified ICT in the relapse situation, however, also documenting a significantly worse outcome for those 94 patients, who had relapsed following initial rituximabcontaining regimens [10]. Overall, data on outcome after repeated rituximab therapy for patients in relapse after initial ICT are still scarce, and the optimal strategy to achieve consolidation of second remission is currently unknown (reviewed in [11]). Similarly in mantle cell lymphoma (MCL), several studies have documented the value of ICT with rituximab to improve response rates, progression free, and overall survival [11]. Approaches combining rituximab with high-dose chemotherapy regimens including methotrexate and cytarabine with and without stem cell support led to further improvements of treatment results, still leaving, however, a significant proportion of patients to relapse [12-14]. Again, patients were found to experience significant benefit from the addition of rituximab to salvage protocols [15], and data for patients in the situation of relapsed disease following initial rituximab exposure are scarce. We report here a retrospective analysis from a lymphoma referral centre, analysing patients with aggressive lymphomas failing from first-line immunochemotherapy with R-CHOP-like regimens (rituximab, cyclophosphamide, adriamycin, vincristine, and prednisone). This analysis was conducted to expand the data on the response rate to second-line ICT and long-term remissions with any therapy after failure of initial immunochemotherapy.

\section{Materials and methods}

\section{Inclusion criteria}

On the basis of ICD-10 coding C83 and C85.1, we identified 51 lymphoma patients treated between December 2002 and May 2008 at the University Medicine Goettingen, Germany. Included were subjects with histopathologically confirmed diagnosis of DLBCL and MCL at age $>18$ years that received salvage/retherapy with at least one cycle of rituximab due to primarily refractory or relapsed lymphoma after first-line immunochemotherapy with rituximab. Patients with primary central nervous system involvement, CD20 negative B cell lymphomas, maintenance therapy with Rituximab for MCL patients within trials, and absence of progression or refractory disease were ineligible. Patients were included independent from a participation in clinical trials. This retrospective analysis of treatment was submitted to the ethics committee of the University Medicine of Goettingen, Germany, and no objections were raised.
Design of analysis/response assessment

Data acquisition comprised information concerning time of diagnosis, age at diagnosis, gender, stage of disease according to the Ann Arbor classification, B symptoms, Eastern Cooperative Oncology Group performance status, bone marrow involvement, lactate dehydrogenase summarised in the International Payment Instruction (IPI), applied first immunochemotherapy, and response to first-line therapy (complete remission/partial remission (CR/PR) vs stable disease/progressive disease (SD/PD)), number of given rituximab cycles in first-line therapy, time to progression, and relapse after first ICT, respectively. Further information included high-dose therapy including autologous and allogeneic stem cell transplantation (matched and mismatched related vs unrelated donors), date of last to follow up, status of disease at last follow up, as well as death. Progression free survival was defined as the interval between start of initial or second immunochemotherapy and death or lymphoma progression, whichever occurred first. Response was defined as CR/PR in imaging meaning a reduction of tumour load more than $50 \%$ in volume after therapy regardless of the duration, non-response, therefore, was progressive disease/no change or reduction of tumour load less than $50 \%$. Patients who died without documentation of progression were considered to have had tumour progression on the date of death, unless documented evidence indicated that no progression occurred. Data acquisition was based on recorded patient files and survival information acquired from public registration office. Unavailable data were censored.

\section{Statistical analysis}

Progression-free survival was calculated from the date of diagnosis to documented disease progression; observations were censored on the date the patient was last known to be alive, or for patients dying as a result of causes unrelated to lymphoma or treatment at the date of death. Overall survival was calculated from the date of diagnosis or the start of second immunochemotherapy until death as a result of any cause or date last known alive. The times to event distributions were estimated using the Kaplan-Meier method. All statistics were calculated using Statistica 8 software.

\section{Results}

Response to second-line immunotherapy

Fifty-one patients with prior rituximab immunochemotherapy were eligible for this retrospective analysis, 28 with 
relapsing or progressive DLBCL, and 23 patients with relapse of MCL (Table 1) with a median follow up of 497 days for DLBCL and 1,051 days for MCL after initial diagnosis. The median time to treatment failure after first ICT with R-CHOP-like regimens was 225 days (range 71963) in DLBCL and 374 days (range $60-1,470$ ) in MCL (Table 1a).

The second ICT patients received rituximab at a mean number of 2.1 courses in DLBCL (range 1-4) and 2.6 courses (range 1-6) in MCL with $375 \mathrm{mg} / \mathrm{m}^{2}$ each, together with chemotherapy consisting mainly of R-DHAP and RICE (Table 1a). Six out of 28 patients with DLBCL and one with MCL received dexamethasone and carmustine, etoposide, cytarabine, and melphalan (DexaBEAM), one patient with DLBCL, and four patients with MCL received rituximab and bendamustine. A response to second ICT with $\mathrm{CR} / \mathrm{PR}$ was seen in 9 of $28(32 \%)$ patients with DLBCL and in 16 of $23(70 \%)$ with MCL.

Comparing response to immunotherapy in first- and second-line therapy, we found that in 18 of $28(64.3 \%)$ patients with DLBCL the disease had responded to first-line therapy. Of the responding patients, the disease responded in 9 of $18(50 \%)$ for a second time, whereas, those patients that were progressive under R-CHOP-like regimens did not reach remissions with second-line ICT (Fig. 1). In the patients with MCL, response to first-line immunochemotherapy had been achieved in 21 of 23 (91.3\%) patients. There were consecutive second-line immunotherapyinduced remissions in 16 of $21(76.2 \%)$ cases. Again, second-line immunotherapy did not lead to remissions in those two cases, in which responses to first-line therapy could not be achieved (Fig. 1). Thus, in patients with DLBCL and mantle cell lymphoma refractory to primary rituximab/CHOP-based ICT, rituximab containing ICT regimens applying DHAP or ICE were ineffective.

Treatment outcome after second-line immunotherapy in patients with DLBCL

In 19 of 28 patients with relapsed or refractory DLBCL, salvage ICT was ineffective, and of the remaining nine patients with responding disease, seven patients experienced second relapse. The median time to treatment failure from second immunochemotherapy was 74 days (range 13415 days, Fig. 2a). Ineffective salvage therapy or secondary relapses lead to further salvage strategies, mainly consisting of chemotherapy according to the B acute lymphoblastic leukaemia protocol and high-dose regimens or palliative chemotherapy. The median survival since start of second ICT amounted to 214 days (range 19-1,260 days) in the group of non-responders and an overall survival for all patients with DLBCL to 243 days with ten patients alive at last follow up (Fig. 2b).
Thirteen patients did not proceed to high-dose chemotherapy with stem cell transplantation either due to comorbidity or progressive disease. Only one patient not receiving transplantation survived beyond one year despite further treatment in palliative intention in most patients.

Consecutively, fifteen patients received high-dose chemotherapy followed by autologous transplantation in nine patients and soley allogeneic transplantation in six patients. After autologous stem cell transplantation, one patient was in complete remission, one patient experienced progressive disease and did not receive further intensified therapy, one received consolidating allogeneic stem cell transplantation in partial remission, and five patients with persistent or progressive disease received an allogeneic transplantation after further salvage therapy. Of the twelve patients receiving allogeneic stem cell transplantation, four patients experienced progressive disease, two patients died due to treatment related mortality after allogeneic stem cell transplantation with status of disease not assessed, and, further, four patients died due to infectious complications without evidence of disease. Two patients are alive and without disease at day 1,260 and 949 after start of second ICT. Thus, the prognosis of patients with relapse of DLBCL after initial immunotherapy is dismal, with only rare cases of disease control by secondary immunochemotherapy and subsequent high-dose therapy.

Treatment outcome after second-line immunotherapy in patients with $\mathrm{MCL}$

In our cohort of 23 patients with relapsed mantle cell lymphoma, the median time to treatment failure from firstline immunochemotherapy was considerably longer than in DLBCL patients, i.e., 374 days since diagnosis (range 60 1,470). Still, a relapse later than 4 years after diagnosis was recorded only in one patient of this cohort.

Rituximab-containing salvage therapies succeeded in second remissions for sixteen patients. Five patients did not respond to second immunochemotherapy, and in seven patients second remissions were not durable leading to a median time to treatment failure of 270 days (Fig. 2c). Therefore, further salvage therapies and consolidating highdose therapy followed by either autologous or allogeneic stem cell transplantations in eight and five patients were applied. Six patients after autologous transplantations and all five patients after allogeneic transplantations experienced stable complete remissions. Following allogeneic transplantation, however, two patients succumbed to infectious complications at day 270 and 419 post-second ICT. Overall, sixteen patients with relapsed MCL were alive at a median interval of 336 days after second ICT (range 861,609, mean 591 days, Fig. 2c and d). Thus, second immunochemotherapy with rituximab was beneficial for 
Table 1 Patients' characteristics

\begin{tabular}{|c|c|c|c|c|}
\hline a & DLBCL (number of patients) & Percent & MCL (number of patients) & Percent \\
\hline Number of patients & 28 & & 23 & \\
\hline Male/female & $14 / 14$ & & $17 / 6$ & \\
\hline Median age in years (range) & $51(19-74)$ & & $57(37-76)$ & \\
\hline$N>60 \quad$ years & 8 & 29 & 11 & 48 \\
\hline \multicolumn{5}{|l|}{ Stage } \\
\hline 1,2 & 5 & 18 & 2 & 9 \\
\hline 3,4 & 23 & 82 & 21 & 91 \\
\hline $\mathrm{IPI} \geq 2$ & 21 & 75 & 13 & 57 \\
\hline Bulky Disease $\geq 7.5 \mathrm{~cm}$ & 12 & 43 & 3 & 13 \\
\hline \multicolumn{5}{|l|}{ First line ICT } \\
\hline R-CHO(E)P 14/21 & 26 & 93 & 22 & 96 \\
\hline R-MegaCHOEP & 1 & 4 & & \\
\hline $\begin{array}{l}\text { Other } \\
\text { Mean no. rituximab applications (range) }\end{array}$ & $\begin{array}{l}1^{*} \\
6,21(1-10)\end{array}$ & 4 & $\begin{array}{l}1 \Delta \\
6,04(2-8)\end{array}$ & 4 \\
\hline radiotherapy & 6 & 21 & 1 & 4 \\
\hline \multicolumn{5}{|l|}{ Response to first ICT } \\
\hline $\mathrm{CR} / \mathrm{PR}$ & 18 & 64 & 21 & 92 \\
\hline $\mathrm{SD} / \mathrm{PD}$ & 10 & 36 & 2 & 8 \\
\hline \multicolumn{5}{|l|}{$\mathrm{b}$} \\
\hline Median TTF first ICT in days (range) & $225(71-963)$ & & $374(60-1470)$ & \\
\hline \multicolumn{5}{|l|}{ Status pre-second ICT } \\
\hline Early relapse & 16 & 57 & 14 & 61 \\
\hline Late relapse (>1 year) & 2 & 7 & 7 & 30 \\
\hline Primary refractory & 10 & 36 & 2 & 9 \\
\hline \multicolumn{5}{|l|}{ Second ICT* } \\
\hline R-DHAP & 14 & 50 & 6 & 26 \\
\hline R-ICE & 8 & 29 & 5 & 22 \\
\hline R-DexaBEAM & 6 & 21 & 1 & 4 \\
\hline Other & $7^{\mathrm{a}}$ & 25 & $10^{\mathrm{b}}$ & 43 \\
\hline Mean number R-applications & $2,1(1-4)$ & & $2,6(1-6)$ & \\
\hline \multicolumn{5}{|l|}{ Second ICT response } \\
\hline $\mathrm{CR} / \mathrm{PR}$ & 9 & 32 & 16 & 70 \\
\hline $\mathrm{SD} / \mathrm{PD}$ & 19 & 68 & 7 & 30 \\
\hline \multicolumn{5}{|l|}{ Response second ICT after } \\
\hline a) $\mathrm{CR} / \mathrm{PR}$ post-first ICT & $9 / 18$ & 50 & $16 / 21$ & 76 \\
\hline b) $\mathrm{SD} / \mathrm{PD}$ post-first ICT & $0 / 10$ & 0 & $0 / 2$ & 0 \\
\hline \multicolumn{5}{|l|}{ Further therapy } \\
\hline Autologous SCT & 9 & 32 & 8 & 35 \\
\hline Autologous/allogeneic SCT & 6 & 21 & 0 & 0 \\
\hline Allogeneic SCT & 12 & 43 & 5 & 22 \\
\hline \multicolumn{5}{|l|}{ Remission allogeneic SCT } \\
\hline $\mathrm{CR} / \mathrm{PR}$ & 6 & 21 & 5 & 22 \\
\hline $\mathrm{SD} / \mathrm{PD}$ & 4 & 14 & 0 & 0 \\
\hline not applicable & 2 & 7 & 0 & 0 \\
\hline
\end{tabular}

Listed are the characteristics of patients of a primary and $\mathbf{b}$ secondary immunochemotherapy with relapsing DLBCL and MCL

*One cycle rituximab, ifosfamide, etoposide, vincristine plus three cycles of cyclophosphamide, idarubicine, vincristine, DexaBEAM, and autologous SCT $\Delta$ Mitoxantrone, chlorambucil, and prednisolone

${ }^{a}$ 1x R-cyclophosphamide, doxorubicin, vincristine, prednisone, 1x R-etoposide, cytarabine, cisplatin and prednisolone; 1x R-dexamethasone, vincristine, high-dose methotrexate, ifosfamide, cytarabine, etoposide (B-ALL protocol); and 1x R-dexamethasone, gemcitabine and oxaliplatin);

${ }^{\mathrm{b}}$ Ibritumomab tiuxetan 


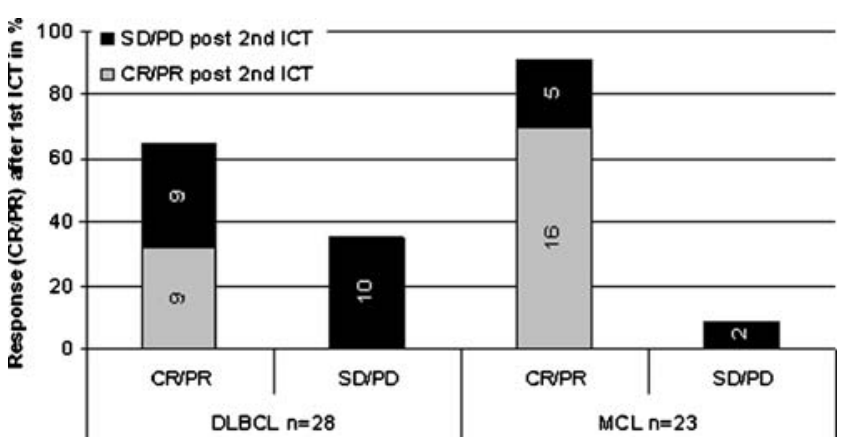

Fig. 1 Response to second immunochemotherapy depending on the response to first-line immunochemotherapy with rituximab. Patients were classified into responders to first ICT or non-responders, defined as achieving at least partial remission (PR) versus stable disease (SD) or progressive disease (PD). The proportion diseases responding to first-line ICT is given on the $x$-axis. Grey bars indicate responsive disease to second ICT, whereas, non-response is depicted in black bars, with absolute numbers of patients displayed within the bars

most patients with relapsed MCL, particularly, if consolidation with high-dose therapy and stem cell transplantation was provided.

\section{Discussion}

A decade after its introduction [16, 17], the monoclonal anti-CD20 antibody rituximab represents the standard of care in first-line therapy for patients with aggressive CD20positive $\mathrm{B}$ cell lymphoma leading to increase in cure and reducing the risk of relapses. For patients being refractory to or relapse after initial ICT, the optimal salvage regimens remain to be defined.

In the present analysis, the efficacy of repeated immunotherapy and the long-term outcome were analysed in a cohort of patients after prior exposure to rituximab. We found an overall low response rate of $32 \%$ ( 9 of 28 patients) to rituximab containing salvage therapy in DLBCL, well in accordance with the findings in comparable cohorts of patients [18]. Similarly, in the ongoing European phase III trial comparing the response rates to R-ICE and R-DHAP salvage therapy followed by high-dose therapy with autologous stem cell transplantation (CORAL trial), prior exposure to rituximab was associated with a significant loss in event-free survival after 24 months, i.e., $66 \%$ without rituximab pre-treatment vs 34\% [19]. Noteworthy, none of our 12 patients with initially refractory disease reached a remission with second ICT. Thus, therapeutic approaches comprising immunochemotherapy and autologous stem cell transplantation seem insufficient to induce long-lasting remission for the majority of patients with refractory DLBCL. Also for patients with relapses of mantle cell lymphoma after front-line induction ICT, salvage therapy with rituximab therapy yielded lower response rates when compared to the situation in rituximab naive patients [20]. The response rate of $69 \%$ (16 of 23 patients) in patients with MCL, however, compares favourably to the dismal situation in DLBCL. For patients achieving a second remission, high-dose therapy followed by stem cell transplantation, particularly from an allogeneic source, resulted in prolonged intervals of progression-free survival intervals.
Fig. 2 Kaplan-Meier estimates of progression-free survival and overall survival in patients with DLBCL and MCL after second immunochemotherapy. Time to progression $(\mathrm{a}, \mathrm{c})$ and overall survival $(b, d)$ in days after second-line immunochemotherapy are displayed for patients with relapsed DLBCL $(a, b)$ and MCL (c, d). The asterisk (*) indicates patients that received allogeneic stem cell transplantation
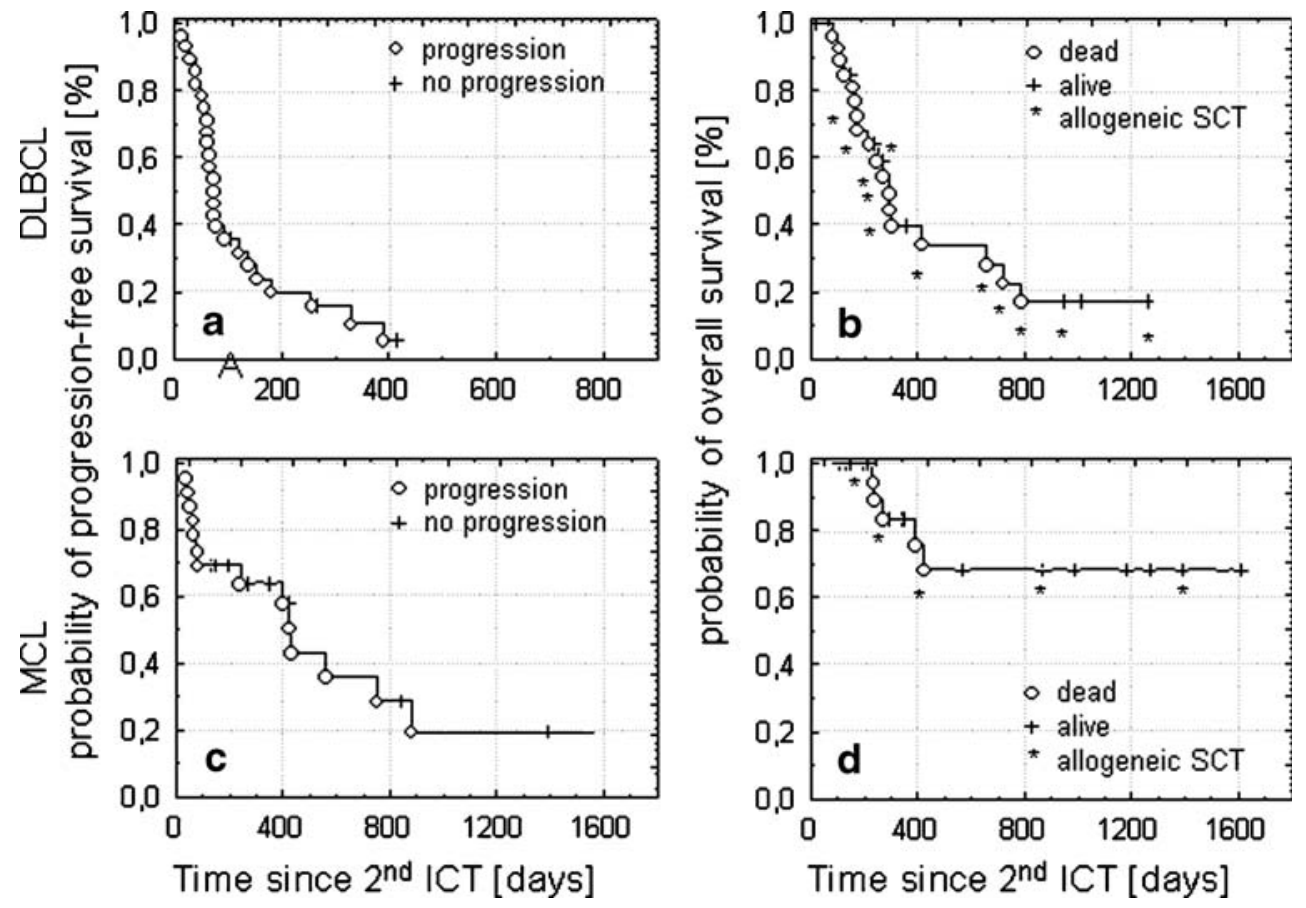
The mechanisms of resistance to rituximab in the relapse situation are yet not well understood, but may result from loss of CD20-antigen expression [21-23], the activation of B cell survival pathways [24], an increased expression of the complement inhibitors CD55 and CD59 [25, 26], or from impaired functions of the cellular mediators of antibody dependent cellular cytotoxicity [27-30].

Allogeneic stem cell transplantation was the only option to induce long-lasting remissions in our cohort of patients with relapsed aggressive lymphomas, implicating an immunologic surveillance as the important determinant in tumour eradication. In the patients with aggressive lymphomas, remissions were induced in six out of 12 heavily pretreated patients, a result also achieved for patients for all five patients with MCL. Due to its inherent toxicity, as well as limitations in donor availability, however, allogeneic stem cell transplantation may not represent a realistic option to all patients in second remission, documenting an urgent need for novel agents in the situation of relapsed aggressive lymphoma.

In summary, responses to second immunotherapy with rituximab could be achieved for one third of patients with DLBCL and two thirds of patients with MCL pre-treated with rituximab. The situation of patients with primarily refractory disease appears dismal. High-dose chemotherapy followed by stem cell transplantation, particularly from an allogeneic donor, was the only option of consolidating treatment sufficient to secure durable remissions.

Open Access This article is distributed under the terms of the Creative Commons Attribution Noncommercial License which permits any noncommercial use, distribution, and reproduction in any medium, provided the original author(s) and source are credited.

\section{References}

1. Coiffier B, Lepage E, Briere J, Herbrecht R, Tilly H, Bouabdallah R, Morel P, Van Den NE, Salles G, Gaulard P, Reyes F, Lederlin P, Gisselbrecht C (2002) CHOP chemotherapy plus rituximab compared with CHOP alone in elderly patients with diffuse large B cell lymphoma. N Engl J Med 346:235-242

2. Glass B, Kloess M, Reiser M, Metzner B, Truemper LH, Loeffler M, Pfreundschuh M, Schmitz N (2005) Dose escalated CHOP + etoposide followed by repetitive autologous stem cell transplantation (MegaCHOEP) with or without rituximab for primary treatment of aggressive NHL. ASH Annual Meeting Abstracts 106:1492

3. Pfreundschuh M, Trumper L, Osterborg A, Pettengell R, Trneny M, Imrie K, Ma D, Gill D, Walewski J, Zinzani PL, Stahel R, Kvaloy S, Shpilberg O, Jaeger U, Hansen M, Lehtinen T, LopezGuillermo A, Corrado C, Scheliga A, Milpied N, Mendila M, Rashford M, Kuhnt E, Loeffler M (2006) CHOP-like chemotherapy plus rituximab versus CHOP-like chemotherapy alone in young patients with good-prognosis diffuse large B cell lympho- ma: a randomised controlled trial by the MabThera International Trial (MInT) Group. Lancet Oncol 7:379-391

4. Pfreundschuh M, Schubert J, Ziepert M, Schmits R, Mohren M, Lengfelder E, Reiser M, Nickenig C, Clemens M, Peter N, Bokemeyer C, Eimermacher H, Ho A, Hoffmann M, Mertelsmann R, Trumper L, Balleisen L, Liersch R, Metzner B, Hartmann F, Glass B, Poeschel V, Schmitz N, Ruebe C, Feller AC, Loeffler M (2008) Six versus eight cycles of bi-weekly CHOP-14 with or without rituximab in elderly patients with aggressive CD20+ B cell lymphomas: a randomised controlled trial (RICOVER-60). Lancet Oncol 9:105-116

5. Feugier P, van Hoof A, Sebban C, Solal-Celigny P, Bouabdallah R, Ferme C, Christian B, Lepage E, Tilly H, Morschhauser F, Gaulard P, Salles G, Bosly A, Gisselbrecht C, Reyes F, Coiffier B (2005) Long-term results of the R-CHOP study in the treatment of elderly patients with diffuse large B cell lymphoma: a study by the Groupe d'Etude des Lymphomes de l'Adulte. J Clin Oncol 23:4117-4126

6. Mey UJ, Olivieri A, Orlopp KS, Rabe C, Strehl JW, Gorschlueter M, Hensel M, Flieger D, Glasmacher AG, Schmidt-Wolf IG (2006) DHAP in combination with rituximab vs DHAP alone as salvage treatment for patients with relapsed or refractory diffuse large B cell lymphoma: a matched-pair analysis. Leuk Lymphoma 47:2558-2566

7. Zelenetz AD, Hamlin P, Kewalramani T, Yahalom J, Nimer S, Moskowitz CH (2003) Ifosfamide, carboplatin, etoposide (ICE)based second-line chemotherapy for the management of relapsed and refractory aggressive non-Hodgkin's lymphoma. Ann Oncol 14(Suppl 1):i5-10

8. El Gnaoui T, Dupuis J, Belhadj K, Jais JP, Rahmouni A, CopieBergman C, Gaillard I, Divine M, Tabah-Fisch I, Reyes F, Haioun C (2007) Rituximab, gemcitabine and oxaliplatin: an effective salvage regimen for patients with relapsed or refractory B cell lymphoma not candidates for high-dose therapy. Ann Oncol 18:1363-1368

9. Philip T, Guglielmi C, Hagenbeek A, Somers R, Van Der LH, Bron D, Sonneveld P, Gisselbrecht C, Cahn JY, Harousseau JL (1995) Autologous bone marrow transplantation as compared with salvage chemotherapy in relapses of chemotherapy-sensitive nonHodgkin's lymphoma. N Engl J Med 333:1540-1545

10. Martin A, Conde E, Arnan M, Canales MA, Deben G, Sancho JM, Andreu R, Salar A, Garcia-Sanchez P, Vazquez L, Nistal S, Requena MJ, Donato EM, Gonzalez JA, Leon A, Ruiz C, Grande C, Gonzalez-Barca E, Caballero MD (2008) R-ESHAP as salvage therapy for patients with relapsed or refractory diffuse large B cell lymphoma: the influence of prior exposure to rituximab on outcome. A GEL/TAMO study. Haematologica 93:1829-1836

11. Gisselbrecht C (2008) Use of rituximab in diffuse large B-cell lymphoma in the salvage setting. Br J Haematol 143:607-621

12. Geisler CH, Kolstad A, Laurell A, Andersen NS, Pedersen LB, Jerkeman M, Eriksson M, Nordstrom M, Kimby E, Boesen AM, Kuittinen O, Lauritzsen GF, Nilsson-Ehle H, Ralfkiaer E, Akerman M, Ehinger M, Sundstrom C, Langholm R, Delabie J, Karjalainen-Lindsberg ML, Brown P, Elonen E (2008) Long-term progression-free survival of mantle cell lymphoma after intensive front-line immunochemotherapy with in vivo-purged stem cell rescue: a nonrandomized phase 2 multicenter study by the Nordic Lymphoma Group. Blood 112:2687-2693

13. Dreyling M, Lenz G, Hoster E, van Hoof A, Gisselbrecht C, Schmits R, Metzner B, Truemper L, Reiser M, Steinhauer H, Boiron JM, Boogaerts MA, Aldaoud A, Silingardi V, KluinNelemans HC, Hasford J, Parwaresch R, Unterhalt M, Hiddemann W (2005) Early consolidation by myeloablative radiochemotherapy followed by autologous stem cell transplantation in first remission significantly prolongs progression-free survival in mantle-cell lymphoma: results of a prospective 
randomized trial of the European MCL Network. Blood 105:2677-2684

14. Romaguera JE, Fayad L, Rodriguez MA, Broglio KR, Hagemeister FB, Pro B, McLaughlin P, Younes A, Samaniego F, Goy A, Sarris AH, Dang NH, Wang M, Beasley V, Medeiros LJ, Katz RL, Gagneja H, Samuels BI, Smith TL, Cabanillas FF (2005) High rate of durable remissions after treatment of newly diagnosed aggressive mantle-cell lymphoma with rituximab plus hyper-CVAD alternating with rituximab plus high-dose methotrexate and cytarabine. J Clin Oncol 23:7013-7023

15. Forstpointner R, Dreyling M, Repp R, Hermann S, Hanel A, Metzner B, Pott C, Hartmann F, Rothmann F, Rohrberg R, Bock HP, Wandt H, Unterhalt M, Hiddemann W (2004) The addition of rituximab to a combination of fludarabine, cyclophosphamide, mitoxantrone (FCM) significantly increases the response rate and prolongs survival as compared with FCM alone in patients with relapsed and refractory follicular and mantle cell lymphomas: results of a prospective randomized study of the German LowGrade Lymphoma Study Group. Blood 104:3064-3071

16. Maloney DG, Grillo-Lopez AJ, White CA, Bodkin D, Schilder RJ, Neidhart JA, Janakiraman N, Foon KA, Liles TM, Dallaire BK, Wey K, Royston I, Davis T, Levy R (1997) IDEC-C2B8 (Rituximab) anti-CD20 monoclonal antibody therapy in patients with relapsed low-grade non-Hodgkin's lymphoma. Blood 90:2188-2195

17. Coiffier B, Haioun C, Ketterer N, Engert A, Tilly H, Ma D, Johnson P, Lister A, Feuring-Buske M, Radford JA, Capdeville R, Diehl V, Reyes F (1998) Rituximab (anti-CD20 monoclonal antibody) for the treatment of patients with relapsing or refractory aggressive lymphoma: a multicenter phase II study. Blood 92:1927-1932

18. Palacios A, Navarrete M, Gallur L, Zuazu J, Barrenetxea C, Sanchez E, Lopez A (2006) Re-treatment with rituximab plus chemotherapy in patients with aggressive lymphoma treated previously with $\mathrm{CHOP}$ or CHOP-like combinations plus rituximab. ASH Annual Meeting Abstracts 108:4707

19. Gisselbrecht C, Schmitz N, Mounier N, Ma D, Trneny M, Hagberg H, Linch DC, Shpilberg O, Ketterer N, Glass B, Bosly A, Gill D, Gaulard P, Moskowitz C (2007) R-ICE versus R-DHAP in relapsed patients with CD20 diffuse large B cell lymphoma (DLBCL) followed by stem cell transplantation and maintenance treatment with rituximab or not: first interim analysis on 200 patients. CORAL Study. ASH Annual Meeting Abstracts 110:517

20. Weide R, Hess G, Koppler H, Heymanns J, Thomalla J, Aldaoud A, Losem C, Schmitz S, Haak U, Huber C, Unterhalt M, Hiddemann W, Dreyling M (2007) High anti-lymphoma activity of bendamustine/mitoxantrone/rituximab in rituximab pretreated relapsed or refractory indolent lymphomas and mantle cell lymphomas. A multicenter phase II study of the German Low Grade Lymphoma Study Group (GLSG). Leuk Lymphoma 48:1299-1306

21. Foran JM, Norton AJ, Micallef IN, Taussig DC, Amess JA, Rohatiner AZ, Lister TA (2001) Loss of CD20 expression following treatment with rituximab (chimaeric monoclonal antiCD20): a retrospective cohort analysis. Br J Haematol 114:881883

22. Johnson NA, Leach S, Woolcock B, deLeeuw RJ, Bashashati A, Sehn LH, Connors JM, Chhanabhai M, Brooks-Wilson A, Gascoyne RD (2009) CD20 mutations involving the rituximab epitope are rare in diffuse large B cell lymphomas and are not a significant cause of R-CHOP failure. Haematologica 94:423-427

23. Maeshima AM, Taniguchi H, Nomoto J, Maruyama D, Kim SW, Watanabe T, Kobayashi Y, Tobinai K, Matsuno Y (2009) Histological and immunophenotypic changes in 59 cases of $\mathrm{B}$ cell non-Hodgkin's lymphoma after rituximab therapy. Cancer Sci 100:54-61

24. Jazirehi AR, Vega MI, Bonavida B (2007) Development of rituximab-resistant lymphoma clones with altered cell signaling and cross-resistance to chemotherapy. Cancer Res 67:1270-1281

25. Golay J, Lazzari M, Facchinetti V, Bernasconi S, Borleri G, Barbui T, Rambaldi A, Introna M (2001) CD20 levels determine the in vitro susceptibility to rituximab and complement of B cell chronic lymphocytic leukemia: further regulation by CD55 and CD59. Blood 98:3383-3389

26. Dalle S, Dupire S, Brunet-Manquat S, Reslan L, Plesa A, Dumontet C (2009) In vivo model of follicular lymphoma resistant to rituximab. Clin Cancer Res 15:851-857

27. Gluck WL, Hurst D, Yuen A, Levine AM, Dayton MA, Gockerman JP, Lucas J, Denis-Mize K, Tong B, Navis D, Difrancesco A, Milan S, Wilson SE, Wolin M (2004) Phase I studies of interleukin (IL)-2 and rituximab in B cell non-hodgkin's lymphoma: IL-2 mediated natural killer cell expansion correlations with clinical response. Clin Cancer Res 10:2253-2264

28. Cartron G, Watier H, Golay J, Solal-Celigny P (2004) From the bench to the bedside: ways to improve rituximab efficacy. Blood 104:2635-2642

29. Dall'Ozzo S, Tartas S, Paintaud G, Cartron G, Colombat P, Bardos P, Watier H, Thibault G (2004) Rituximab-dependent cytotoxicity by natural killer cells: influence of FCGR3A polymorphism on the concentration-effect relationship. Cancer Res 64:4664-4669

30. Weng WK, Levy R (2003) Two immunoglobulin G fragment C receptor polymorphisms independently predict response to rituximab in patients with follicular lymphoma. J Clin Oncol 21:3940 3947 